\title{
Bridged 2,2'-Biazole Derivatives by 1,3-Dipolar Cycloaddition
}

\author{
Maria S. de Pablo, Teresa Gandásegui, Juan J. Vaquero, José L. García Navío and Julio Alvarez-Builla*
}

Departamento de Química Orgánica. Universidad de Alcalá. Alcalá de Henares. Madrid.Spain.

(Received in UK 27 July 1992)

\begin{abstract}
Azomethine ylides derived from 3,4-dihydropyrrolo[1,2-a]pyrazinium salts undergo 1,3-dipolar cycloaddition reactions to yield 5,6-dihydrodipyrrolo[1,2-a:2',1'-c]-pyrazine and 5,6-dihydroimidazo[1,2-a]pyrrolo[2,1-c]pyrazin-4-inium-2-olate and 2-thiolate derivatives. S-Methylation followed by nucleophilic displacement of methylthio group converted the 2-thiolate derivatives into new conjugated betaines.
\end{abstract}

The properties of bridged azabiaryl systems in which a polymethylene bridge may be used to control the conformation (1, Scheme 1) are strongly influenced by both electronic and steric factors. Moreover, the interaction of covalently bound $\pi$-systems is favoured by a planar conformation which provides the optimum environment for resonance delocalization. Such interaction has been found to influence both the physical and chemical properties with important implications on the coordination chemistry of the biheteroaryl molecules..$^{1,2}$ When the introduction of an $\mathrm{N}, \mathrm{N}^{\prime}$-bridge can lead to quaternary salts, ${ }^{3.5}$ the systems are capable of behaving as viologens, ${ }^{6}$ a special class of $\mathrm{N}$-substituted salts with reversible electron acceptor properties, applied as redox catalysts and electron relays in photocatalysed water cleavage $^{7,8}$ and as effective herbicides. ${ }^{9}$

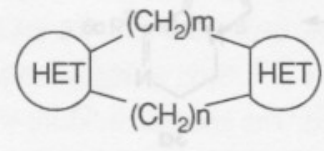

1

HET=Hetercaromatic

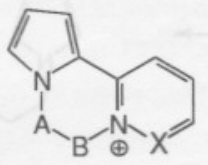

2 $\mathrm{X}=\mathrm{CH}, \mathrm{N}$

scheme 1

Our previous experience in this field has been the preparation of pyrido[1,2-a]- and pyridazino[2,3-a] pyrrolo[2,1-c]pyrazin-7-ium derivatives as an example of quaternary systems (2, Scheme 1), in which spectroscopic data showed transfer of electron density ${ }^{10}$ between the heteroaryl moieties. 
The interest of such compounds prompted us to investigate the development of related derivatives. Initially we directed our attention to bridged bipyrroles and we found that previously reported, dipyrrolo[1,2-a:2',1'-c]pyrazines and their 5,6-dihydroderivatives have been prepared either by Chichibabin reaction on a pyrrolo[1,2-a]pyrazinium salt ${ }^{11}$ or by intramolecular oxidative coupling of $1,2-\mathrm{N}, \mathrm{N}$-dipyrrolethane. ${ }^{12}$

Our interest in representative series of these and analogous biazole derivatives led us to explore the use of 1,3-dipolar cycloaddition reaction on azomethine ylides ${ }^{13}$ as a convenient method to prepare this class of compounds. Herein we report preliminary results of our studies.

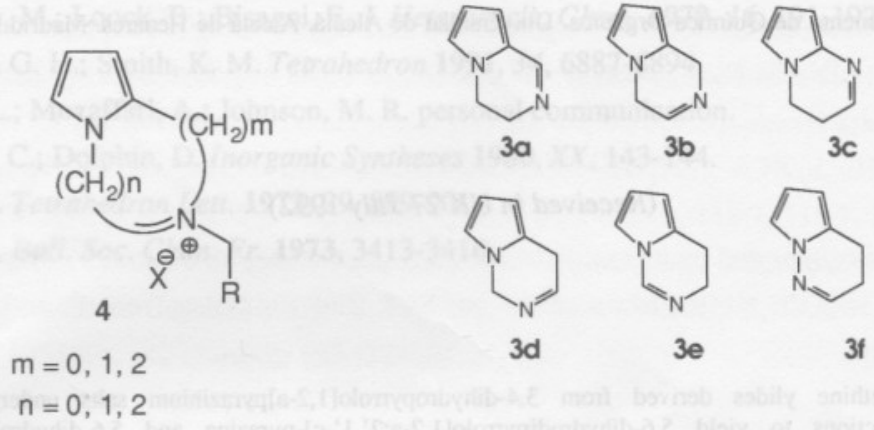

\section{Scheme 2}

At the outset it was envisaged that diverse bridged bipyrrole derivatives could be formed by dipolar cycloaddition of azomethine ylides generated from dihydropyrrolo[1,2-a]pyrazinium, -pyridazinium and -pyrimidinium salts $\mathbf{4}$ with appropriate dipolarophiles. To our surprise, we found that only one of the six possible isomeric structures 3 required, the 3,4-dihydropirrolo[1,2-a]pyrazine $3 \mathbf{a}$ has been reported, and we focused our attention on it as our initial target.

The starting 3,4-dihydropyrrolo[1,2-a]pyrazine system was prepared either by the method of Flament and $\mathrm{col}^{14}$ or by an improved alternative developed by us. ${ }^{15}$ In our method this compound was prepared from pyrrole according to the scheme 3 in a $42 \%$ overall yield (29\% in Flament's method, ref. 15).

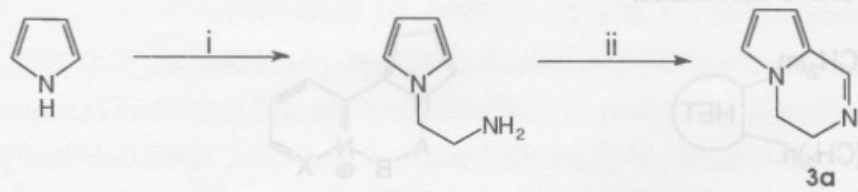

Scheme 3. i) $\mathrm{ClCH}_{2} \mathrm{CH}_{2} \mathrm{NH}_{2} \cdot \mathrm{HCl} / \mathrm{NaOH} / \mathrm{CH}_{3} \mathrm{CN} / \mathrm{TBAS}$, r e f I u x; ii) $\mathrm{HCO}_{2} \mathrm{H}, \mathrm{r}$ ef I u x

The salts $\mathbf{4 a}$ and $\mathbf{4 b}$ were prepared by $\mathrm{N}$-alkylation of the 3,4-dihydrodipyrrolo[1,2-a]pyrazine $\mathbf{3 a}$ with trimethylsilylmethyl trifluoromethanesulfonate ${ }^{16}$ and phenacyl bromide ${ }^{17}$ respectively. Both salts were hygroscopic compounds especially $\mathbf{4 a}$ and this was used without purification after ${ }^{1} \mathrm{H}-\mathrm{nmr}$ analysis. 
Attempts to trap the non-stabilized azomethine ylide generated from $\mathbf{4 a}$ by treatment with caesium fluoride in dimethoxyethan $\mathrm{e}^{16}$ with suitable dipolarophiles failed, with no evidence of formation of the desired cycloadducts. Use of a large excess of dipolarophile, more forcing conditions and different solvents (acetonitrile) and fluoride sources (tetrabutylammonium fluoride and silver fluoride) ${ }^{18}$ also resulted in failure of the cycloaddition reaction, and further work with this salt was abandoned.<smiles>C1CC2CCNCCN2C1</smiles>

3a

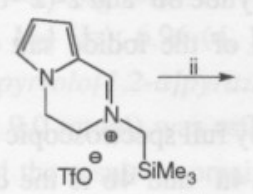

$4 \mathrm{a}$

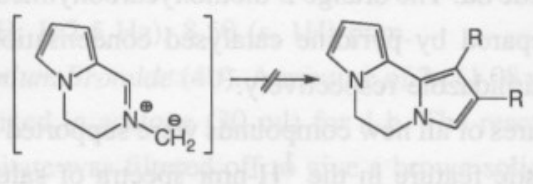

Scheme 4. i) $\mathrm{TFOCH}_{2} \mathrm{SiMe}_{3}, \mathrm{CH}_{2} \mathrm{Cl}_{2}$, r. t.; ii) $\mathrm{F} \Theta$, $\mathrm{R}-\mathrm{C} \equiv \mathrm{C}-\mathrm{R}$

A number of different conditions were examined for the cycloaddition reaction of the benzoyl stabilized ylide generated from $\mathbf{4 b}$ with acetylenes, and the best results were obtained by using two-phase media. ${ }^{19-21}$ Thus, when the process was performed in dichloromethane/50\% aqueous $\mathrm{K}_{2} \mathrm{CO}_{3}$, the best yields of $\mathbf{5 a}(48 \%)$ and $\mathbf{5 b}(49 \%)$ were obtained due to the lack of ylide decomposition.

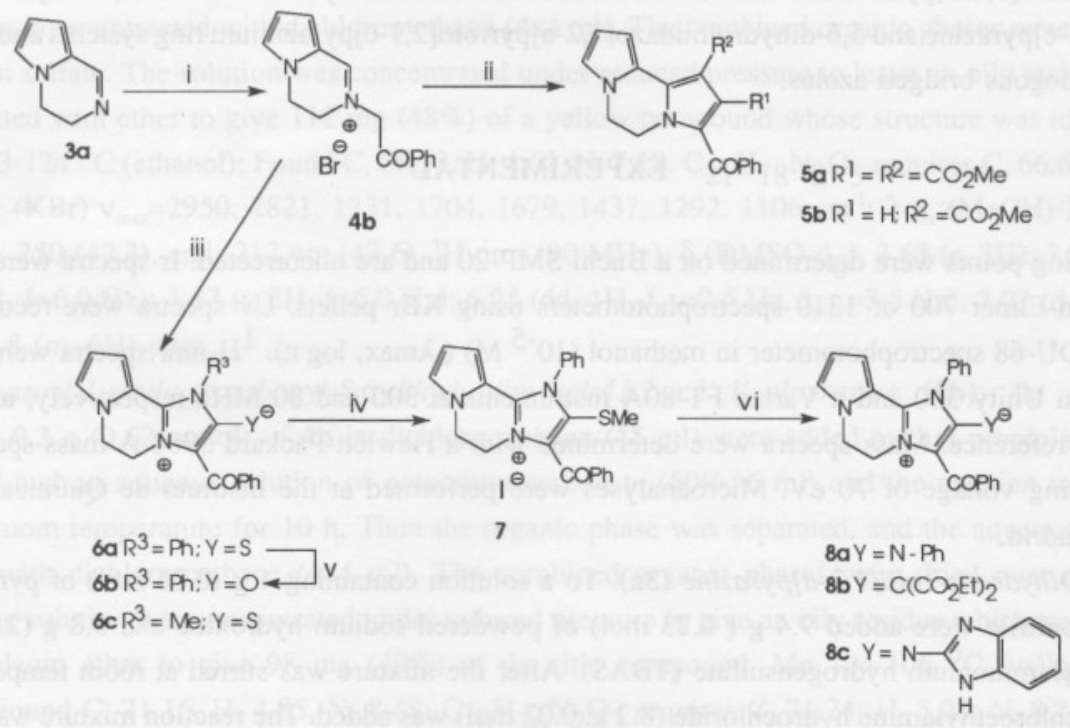

Scheme 5. D) $\mathrm{BrCH} \mathrm{H}_{2} \mathrm{COPh} /$ acetone, r.t; ii) $\mathrm{R}^{1}-\mathrm{C}=\mathrm{C}-\mathrm{R}^{2} / \mathrm{CH}_{2} \mathrm{Cl}_{2} / \mathrm{K}_{2} \mathrm{CO}_{3}$

(aq.. 50\%), r. t.; iii) $\mathrm{R}-\mathrm{N}=\mathrm{C}=\mathrm{Y}, \mathrm{MeCN} / \mathrm{K}_{2} \mathrm{CO}_{3}$, r.t.; iv) $\mathrm{Mel}$, EtOAC, r.t.

v) $\mathrm{MeOH} / \mathrm{NaOH}$ (50\%), r. t. ; vi ) Nucleophile, pyridine, reflux

The cycloaddition reaction of salt $\mathbf{4} \mathbf{b}$ with heterocumulenes under similar conditions was also examined, since it was a potentially a straightforward route to heterobetaines. In this case the best conditions for converting $4 \mathrm{~b}$ to 6 among several examined were $\mathrm{K}_{2} \mathrm{CO}_{3} / \mathrm{CH}_{3} \mathrm{CN}$. In this two-phase medium the mesomeric conjugated betaines $6 \mathrm{a}-\mathrm{c}^{22}$ were obtained in good yield. 
An interest in derivatives containing the imidazo[1,2-a]pyrrolo[2,1-c]pyrazinium system lead us to try to synthesise more representatives of this series of betaines. Thus, the derivative 6 with the thiolate group (scheme 5, 6a, Y=S) was easily transformed into new conjugated betaines by $\mathrm{S}$-methylation to 7 and displacement of the methylthio group by nucleophiles. Thus, basic hydrolysis of $\mathbf{6 a}$ produced $\mathbf{6 b}$, and attack with aniline in pyridine yielded 3-benzoyl-1-phenyl-5,6-dihydroimidazo[1,2-a]pyrrolo[2,1-c]pyrazin4-ium-2-anilide $8 \mathbf{a}$. The orange 2-diethoxycarbonylmethylide $\mathbf{8 b}$ and 2-(2'-benzimidazolylamide) $8 \mathrm{c}$ were similarly prepared by pyridine catalysed condensation of the iodide salt 7 with diethyl malonate and 2-aminobenzimidazole respectively. ${ }^{23}$

Structures of all new compounds were supported by full spectroscopic data and combustion analysis. A characteristic feature in the ${ }^{1} \mathrm{H}-\mathrm{nmr}$ spectra of salts $\mathbf{4 a}$ and $\mathbf{4 b}$ is the chemical shift of $\mathrm{H}-1$ protons which resonate as a singlet at $8.84 \mathrm{ppm}$ and $8.50 \mathrm{ppm}$ respectively. This signal is not present in the cycloadducts and the extent of the cycloaddition reaction may be monitored conveniently by ${ }^{1} \mathrm{H}-\mathrm{nmr}$ analysis on the basis of this signal. The analytical and ${ }^{1} \mathrm{H}$-nmr data of the cycloadducts are also consistent with the structures of the 2-thiolate and 2-olate assigned to compounds 6 . The conversion of $\mathbf{6 a}$ into $\mathbf{6 b}$ via the salt 7 is a simple and useful confirmation of the structural feature of these betaines.

In summary, although the attempted 1,3-dipolar cycloaddition reaction to 3,4-dihydropyrrolo[1,2-a]pyrazine azomethine ylides failed with non-stabilized ylides, the cycloaddition of 2-phenacyl-3,4dihydropyrrolo[1,2-a]pyrazinium salts offers a direct and efficient synthesis of the 5,6-dihydrodipyrrolo[1,2-a:2',1'-c]pyrazine and 5,6-dihydroimidazo[1,2-a]pyrrolo[2,1-c]pyrazinium ring systems and opens the way to analogous bridged azoles.

\section{EXPERIMENTAL}

Melting points were determined on a Buchi SMP-20 and are uncorrected. Ir spectra were recorded on a Perkin-Elmer 700 or 1310 spectrophotometers using $\mathrm{KBr}$ pellets. Uv spectra were recorded on a Beckman DU-68 spectrophotometer in methanol $\left(10^{-5} \mathrm{M}\right)(\lambda \max , \log \varepsilon) .{ }^{1} \mathrm{H}$-nmr spectra were obtained on a Varian Unity 300 and a Varian FT-80A instruments at 300 and $80 \mathrm{MHz}$ respectively, using TMS as internal reference. Mass spectra were determined with a Hewlett-Packard 5988 A mass spectrometer at an ionizing voltage of $70 \mathrm{eV}$. Microanalyses were performed at the Instituto de Química Organica (CSIC), Madrid.

3,4-Dihydropyrrolo[1,2-a]pyrazine (3a). To a solution containing $4 \mathrm{~g}(0.06 \mathrm{~mol})$ of pyrrole in 33 $\mathrm{ml}$ of acetonitrile were added $9.4 \mathrm{~g}(0.23 \mathrm{~mol})$ of powdered sodium hydroxide and $0.8 \mathrm{~g}(2.36 \mathrm{mmol})$ of tetrabutylammonium hydrogensulfate (TBAS). After the mixture was stirred at room temperature for $30 \mathrm{~min}$, 2-chloroethylamine hydrochloride $(8.2 \mathrm{~g}, 0.07 \mathrm{~mol})$ was added. The reaction mixture was refluxed for $24 \mathrm{~h}$. Then, the inorganic solid was filtered off and the solvent was removed under reduced pressure to give crude 1-(2-aminoethyl)pyrrole $(6.15 \mathrm{~g})$.

The above product was refluxed in formic acid $(98 \%)(45 \mathrm{ml})$ for $15 \mathrm{~h}$ and then concentrated under reduced pressure to give a brown residue which was dissolved in $100 \mathrm{ml}$ of sodium hydroxide solution $(40 \%)$. This solution was extracted in continuous with dichloromethane for $12 \mathrm{~h}$. The organic layer was washed with water until neutral $(4 \times 10 \mathrm{ml})$, dried over magnesium sulfate and evaporated under reduced pressure to give a brown oil which crystallised under vacuum. Mp $27-29^{\circ} \mathrm{C}$ (lit. $26-28^{\circ} \mathrm{C}$, ref. 14). 
2-Trimethylsilylmethyl-3,4-dihydropyrrolo[1,2-a]pyrazinium trifluoromethanesulfonate (4a). A mixture of $3 \mathrm{a}(0.5 \mathrm{~g}, 4.1 \mathrm{mmol})$ and trimethylsilylmethyl trifluoromethanesulfonate $(0.98 \mathrm{~g}, 4.1 \mathrm{mmol})$ in dry dichloromethane $(25 \mathrm{ml})$ was stirred at room temperature under argon for $2 \mathrm{~h}$. The solvent was evaporated under reduced pressure to leave an oily residue which consisted mainly of the salt $4 \mathbf{a}$ (95\% by $\left.{ }^{1} \mathrm{H}-\mathrm{nmr}\right)$ and was used without further purification. $\mathrm{Ir}\left(\mathrm{CHCl}_{3}\right) v_{\max } 3112,1632,1610,1450,1082$ $\mathrm{cm}^{-1} ;{ }^{1} \mathrm{H}-\mathrm{nmr}(80 \mathrm{MHz}), \delta$ (DMSO-d 6$) 0.20(\mathrm{~s}, 9 \mathrm{H}) ; 3.87(\mathrm{~s}, 2 \mathrm{H}) ; 3.4-3.6(\mathrm{~m}, 4 \mathrm{H}) ; 6.28\left(\mathrm{dd}, 1 \mathrm{H}, \mathrm{J}_{6-7}=4\right.$ $\left.\mathrm{Hz}, \mathrm{J}_{7-8}=2.5 \mathrm{~Hz}\right) ; 6.33(\mathrm{~d}, 1 \mathrm{H}, \mathrm{J}=4 \mathrm{~Hz}) ; 6.96(\mathrm{~d}, 1 \mathrm{H}, \mathrm{J}=2.5 \mathrm{~Hz}) ; 8.50(\mathrm{~s}, 1 \mathrm{H}) \mathrm{ppm}$.

2-Phenacyl-3,4-dihydropyrrolol 1,2-a]pyrazinium Bromide (4b). A mixture of 3a (1.08 g, $9.0 \mathrm{mmol})$ and phenacyl bromide $(1.8 \mathrm{~g}, 9.0 \mathrm{mmol})$ was refluxed in acetone $(20 \mathrm{ml})$ for $4 \mathrm{~h}$. The reaction mixture was left overnight at $4{ }^{\circ} \mathrm{C}$ and the resulting precipitate was filtered off to give a brown solid which was crystallised from ethanol-diethyl ether to give $1.82 \mathrm{~g} \mathrm{(63 \% )}$ of the title compound. $\mathrm{Mp} 208-209{ }^{\circ} \mathrm{C}$; Found: $\mathrm{C}, 56.33 ; \mathrm{H}, 4.78 ; \mathrm{N}, 8.82 . \mathrm{C}_{15} \mathrm{H}_{15} \mathrm{BrN}_{2} \mathrm{O}_{2}$ requires $\mathrm{C}, 56,44 ; \mathrm{H}, 4.74 ; \mathrm{N}, 8.78$. Ir $(\mathrm{KBr}) \mathrm{v}_{\max } 3117$, 2903, 1690, 1629, 1190, 1036, $802 \mathrm{~cm}^{-1}$; ${ }^{1} \mathrm{H}-\mathrm{nmr}$ (80 MHz), $\delta$ (DMSO-d 6 ), 4.20 (t, 2H, J=7.0 Hz); 4.42 $(\mathrm{t}, 2 \mathrm{H}, \mathrm{J}=7.0 \mathrm{~Hz}) ; 5.74(\mathrm{~s}, 2 \mathrm{H}) ; 6.6\left(\mathrm{dd}, 1 \mathrm{H}, \mathrm{J}_{6-7}=4.0 \mathrm{~Hz}, \mathrm{~J}_{7.8}=3.0 \mathrm{~Hz}\right) ; 7.4-8.0(\mathrm{~m}, 7 \mathrm{H}) ; 8.84(\mathrm{~s}, 1 \mathrm{H}) \mathrm{ppm}$.

3-Benzoyl-1,2-dimethoxycarbonyl-5,6-dihydrodipyrrolo[1,2-a:2',1'-c]pyrazine (5a). To a solution containing $0.2 \mathrm{~g}(0.62 \mathrm{mmol})$ of $\mathbf{4 b}$ in dichloromethane $(15 \mathrm{ml})$ were added dimethylacetylene dicarboxylate (DMAD) $(120 \mathrm{mg}, 0.84 \mathrm{mmol})$ and an aqueous solution of potassium carbonate $(50 \%, 6$ $\mathrm{ml}$ ) and the mixture was stirred at room temperature for $15 \mathrm{~h}$. Then the organic phase was separated, and the aqueous layer extracted with dichloromethane $(4 \times 4 \mathrm{ml})$. The combined organic phases were dried over magnesium sulfate. The solution was concentrated under reduced pressure to leave an oily residue, which was triturated with ether to give $112 \mathrm{mg} \mathrm{(48 \% )}$ ) of a yellow compound whose structure was identified as 5a. Mp $123-124^{\circ} \mathrm{C}$ (ethanol); Found $\mathrm{C}, 66,52, \mathrm{H}, 4,62, \mathrm{~N}, 7,18 . \mathrm{C}_{21} \mathrm{H}_{18} \mathrm{~N}_{2} \mathrm{O}_{5}$ requires $\mathrm{C}, 66.66 ; \mathrm{H}, 4.80$; $\mathrm{N}, 7.40$. Ir (KBr) $v_{\max }=2950,2821,1731,1704,1679,1437,1292,1106 \mathrm{~cm}^{-1} ; \lambda_{\max }(\mathrm{MeOH}) 372$ (39.5), 314 (40.4), 250 (42.3), and $212 \mathrm{~nm}$ (43.6). ${ }^{1} \mathrm{H}-\mathrm{nmr}$ (80 MHz), $\delta$ (DMSO-d 6 ), 3.63 (s, 3H); 3.82 (s, 3H); $4.41(\mathrm{t}, 2 \mathrm{H}, \mathrm{J}=6.0 \mathrm{~Hz}) ; 4.87(\mathrm{t}, 2 \mathrm{H}, \mathrm{J}=6.0 \mathrm{~Hz}) ; 6.25\left(\mathrm{dd}, 1 \mathrm{H}, \mathrm{J}_{8.9}=2.5 \mathrm{~Hz}, \mathrm{~J}_{9-10}=3.5 \mathrm{~Hz}\right) ; 7.07(\mathrm{~d}, 1 \mathrm{H}, \mathrm{J}=2.5$ $\mathrm{Hz}) ; 7.2-7.8(\mathrm{~m}, 6 \mathrm{H}) \mathrm{ppm}$.

3-Benzoyl-1-methoxycarbonyl-5,6-dihydrodipyrrolol1,2-a:2',1'-clpyrazine (5b). To a solution containing $0.2 \mathrm{~g}(0.62 \mathrm{mmol})$ of $\mathbf{4 b}$ in dichloromethane $(15 \mathrm{ml})$ were added methyl propiolate $(60 \mathrm{mg}$, $0.8 \mathrm{mmol})$ and an aqueous solution of potassium carbonate $(50 \%, 6 \mathrm{ml})$ and the reaction mixture was stirred at room temperature for $10 \mathrm{~h}$. Then the organic phase was separated, and the aqueous layer was extracted with dichloromethane $(4 \times 4 \mathrm{ml})$. The combined organic phases were dried over magnesium sulfate. The solution was concentrated under reduced pressure to give an oily residue which was triturated with petroleum ether to give $98 \mathrm{mg}(49 \%)$ of the title compound. $\mathrm{Mp} 104-106{ }^{\circ} \mathrm{C}$ (yellow powder, ethanol); Found $\mathrm{C}, 71.16, \mathrm{H}, 4.85, \mathrm{~N}, 8.48 . \mathrm{C}_{19} \mathrm{H}_{16} \mathrm{~N}_{2} \mathrm{O}_{3}$ requires $\mathrm{C}, 71.24 ; \mathrm{H}, 5.03 ; \mathrm{N}, 8.75$. $\mathrm{Ir}(\mathrm{KBr})$ $v_{\max }=2947,1706,1617,1472,988 \mathrm{~cm}^{-1}$; ${ }^{1} \mathrm{H}-\mathrm{nmr}(300 \mathrm{MHz}), \delta$ (DMSO-d 6 ), $3.82(\mathrm{~s}, 3 \mathrm{H}) ; 4.41$ (t, 2H, $\mathrm{J}=6.3 \mathrm{~Hz}) ; 4.86(\mathrm{t}, 2 \mathrm{H}, \mathrm{J}=6.3 \mathrm{~Hz}) ; 6.35\left(\mathrm{dd}, 1 \mathrm{H}, \mathrm{J}_{8.9}=2.3 \mathrm{~Hz}, \mathrm{~J}_{9.10}=3.4 \mathrm{~Hz}\right) ; 7.07(\mathrm{~d}, 1 \mathrm{H}, \mathrm{J}=2.3 \mathrm{~Hz}) ; 7.2-7.8$ $(\mathrm{m}, 7 \mathrm{H}) \mathrm{ppm}$.

3-Benzoyl-1-phenyl-5,6-dihydroimidazol1,2-a]pyrrolo[2,1-c]pyrazin-4-ium-2-thiolate (6a). To a stirred two-phase mixture comprising a solution of the salt $\mathbf{4 b}(200 \mathrm{mg}, 0.62 \mathrm{mmol})$ in dry acetonitrile $(12 \mathrm{ml})$ and potassium carbonate $(0.23 \mathrm{~g}, 1.66 \mathrm{mmol})$, phenylisothiocyanate $(100 \mathrm{mg}, 0.74 \mathrm{mmol})$ was added, and stirring was continued at room temperature for $24 \mathrm{~h}$; then the precipitate was filtered and washed with dichloromethane $(3 \times 5 \mathrm{ml})$. The combined organic phases were dried over magnesium sulfate 
and evaporated to leave a pale yellow solid. Silica gel chromatography of this material using a 7:3 hexane-ethyl acetate mixture gave $170 \mathrm{mg}(74 \%)$ of the betaine $6 \mathrm{a} . \mathrm{Mp} 177-179^{\circ} \mathrm{C}$ (acetone); Found: C, 71.25; H, 4,58; N, 11.43. $\mathrm{C}_{22} \mathrm{H}_{17} \mathrm{~N}_{3} \mathrm{OS}$ requires $\mathrm{C}, 71.13 ; \mathrm{H}, 4,61 ; \mathrm{N}, 11.31$. Ir $(\mathrm{KBr}) \mathrm{v}_{\max }=3057$, $2928,1592,1529,1391,1281,1206,1172,1074 \mathrm{~cm}^{-1} ; \lambda_{\max }(\mathrm{MeOH}) 396(36), 332$ (38.5), and $206 \mathrm{~nm}$ (42.1). ${ }^{1} \mathrm{H}-\mathrm{nmr}(300 \mathrm{MHz}), \delta$ (DMSO-d $\left._{6}\right), 4.46$ (t, 2H, J=5.8 Hz); 4.72 (t, 2H, J=6.0 Hz); 5.97 (t, 1H, $\mathrm{J}=3.5 \mathrm{~Hz}) ; 6.36(\mathrm{t}, 1 \mathrm{H}, \mathrm{J}=3.9 \mathrm{~Hz}) ; 7.10(\mathrm{~d}, 1 \mathrm{H}, \mathrm{J}=2.4 \mathrm{~Hz}) ; 7.3-7.5(\mathrm{~m}, 6 \mathrm{H}) ; 7.6-7.8(\mathrm{~m}, 2 \mathrm{H}) ; 8.2-8.3$ $(\mathrm{m}, 2 \mathrm{H}) \mathrm{ppm}$.

3-Benzoyl-1-phenyl-5,6-dihydroimidazo[1,2-a]pyrrolo[2,1-c]pyrazin-4-ium-2-olate (6b). To a stirred two-phase mixture comprising a solution of the salt $\mathbf{4 b}(160 \mathrm{mg}, 0.50 \mathrm{mmol})$ in dry acetonitrile $(7 \mathrm{ml})$ and potassium carbonate $(0.19 \mathrm{~g}, 1.37 \mathrm{mmol})$, phenylisocyanate $(80 \mathrm{mg}, 0.67 \mathrm{mmol})$ was added, and stirring was continued at room temperature for $10 \mathrm{~h}$; then the precipitate was filtered and washed with dichloromethane $(3 \times 4 \mathrm{ml})$. The combined organic phases were dried over magnesium sulfate and evaporated to leave a yellowish oil. Silica gel chromatography of this oil using a 7:3 hexane-ethyl acetate mixture gave $150 \mathrm{mg}(84 \%)$ of the title compound. $\mathrm{Mp} 144-145^{\circ} \mathrm{C}$ (ethanol); Found: $\mathrm{C}, 74.49 ; \mathrm{H}, 4.57$; $\mathrm{N}, 11.53 . \mathrm{C}_{22} \mathrm{H}_{17} \mathrm{~N}_{3} \mathrm{O}_{2}$ requires $\mathrm{C}, 74.35 ; \mathrm{H}, 4.82 ; \mathrm{N}, 11.82$. Ir $(\mathrm{KBr}) \mathrm{v}_{\max }=3053,1666,1600,1538$, $1424,1127,1078 \mathrm{~cm}^{-1} ;{ }^{1} \mathrm{H}-\mathrm{nmr}$ (300 MHz), $\delta$ (DMSO-d 6 ), $4.2-4.5(\mathrm{~m}, 4 \mathrm{H}) ; 5.93$ (d, $\left.1 \mathrm{H}, \mathrm{J}=3.5 \mathrm{~Hz}\right) ; 6.36$ $(\mathrm{t}, 1 \mathrm{H}, \mathrm{J}=3.8 \mathrm{~Hz}) ; 7.2-7.3(\mathrm{~m}, 3 \mathrm{H}) ; 7.5-7.6(\mathrm{~m}, 6 \mathrm{H}) ; 8.0-8.1(\mathrm{~m}, 2 \mathrm{H}) \mathrm{ppm}$.

Alternatively, a solution of $6 \mathrm{a}(100 \mathrm{mg}, 0.27 \mathrm{mmol})$ in methanol $(5 \mathrm{ml})$ was added dropwise to a solution of sodium hydroxide $(0.3 \mathrm{ml}, 50 \%)$ and the reaction mixture was stirred at room temperature for $12 \mathrm{~h}$. The solvent was removed under reduced pressure, water $(5 \mathrm{ml})$ was added to the residue and the solution was extracted with dichloromethane. The organic phase was dried over magnesium sulfate, evaporated and the residue chromatographed on silica gel. Elution with hexane-ethyl acetate afforded 63 $\mathrm{mg}(66 \%)$ of $\mathbf{6 b}$.

3-Benzoyl-1-methyl-5,6-dihydroimidazo[1,2-a]pyrrolo[2,1-c]pyrazin-4-ium-2-thiolate (6c). To a stirred two-phase mixture comprising a solution of the salt $4 \mathrm{~b}(560 \mathrm{mg}, 1.7 \mathrm{mmol})$ in dry acetonitrile (25 $\mathrm{ml})$ and potassium carbonate $(0.66 \mathrm{~g}, 4.78 \mathrm{mmol})$, methylisothiocyanate $(154 \mathrm{mg}, 2.1 \mathrm{mmol})$ was added, and stirring was continued at room temperature for $14 \mathrm{~h}$; then the precipitate was filtered and washed with dichloromethane $(2 \times 5 \mathrm{ml})$. The combined organic phases were dried over magnesium sulfate and evaporated to give a brown solid residue. Silica gel chromatography of this material using a 7:3 hexaneethyl acetate mixture gave $320 \mathrm{mg} \mathrm{(59 \% )}$ of the betaine $6 \mathrm{c}$, which crystallised from hexane-ethyl acetate afforded orange crystals. Mp 151- $152^{\circ} \mathrm{C}$; Found: $\mathrm{C}, 66.08 ; \mathrm{H}, 4,53 ; \mathrm{N}, 13.62 . \mathrm{C}_{17} \mathrm{H}_{15} \mathrm{~N}_{3} \mathrm{OS}$ requires C, 65.99; H, 4,88; N, 13.58. Ir (KBr) $v_{\max }=3065,2925,1697,1605,1365,1076,1037 \mathrm{~cm}^{-1} ;{ }^{1} \mathrm{H}-\mathrm{nmr}(300$ MHz), $\delta$ (DMSO-d $_{6}$ ), 3.94 (s, 3H); $4.42(\mathrm{t}, 2 \mathrm{H}, \mathrm{J}=6.1 \mathrm{~Hz}) ; 4.81(\mathrm{t}, 2 \mathrm{H}, \mathrm{J}=5.9 \mathrm{~Hz}) ; 6.46(\mathrm{t}, 1 \mathrm{H}, \mathrm{J}=3.8 \mathrm{~Hz}$ ); $6.92(\mathrm{~d}, 1 \mathrm{H}, \mathrm{J}=3.9 \mathrm{~Hz}) ; 7.05(\mathrm{~d}, 1 \mathrm{H}, \mathrm{J}=2.5 \mathrm{~Hz}) ; 7.3-7.4(\mathrm{~m}, 2 \mathrm{H}) ; 7.5-7.9(\mathrm{~m}, 3 \mathrm{H}) \mathrm{ppm}$.

3-Benzoyl-1-phenyl-2-methylthio-5,6-dihydroimidazo[1,2-a]pyrrolo[2,1-c]pyrazin-4-iumiodide (7). To a stirred suspension of the betaine $6 \mathrm{a}(150 \mathrm{mg}, 0.4 \mathrm{mmol})$ in dry ethyl acetate $(12 \mathrm{ml})$, methyl iodide $(220 \mathrm{mg}, 1.55 \mathrm{mmol})$ was added, and stirring was continued at room temperature for $48 \mathrm{~h}$. The resultant precipitate was filtered off and recrystallised from ethyl acetate to give the salt $\mathbf{7}$ as pale yellow crystals (180 mg, 88\%). Mp $>260^{\circ} \mathrm{C}$. Found: C,53.98; $\mathrm{H}, 3,85 ; \mathrm{N}, 8.24 . \mathrm{C}_{23} \mathrm{H}_{20} \mathrm{IN}_{3} \mathrm{OS}$ requires C, 53.80; H, 3,92; $\mathrm{N}, 8.18$. Ir $(\mathrm{KBr}) v_{\max }=3078,1642,1608,1375,1227,1010 \mathrm{~cm}^{-1} ; \lambda_{\max }(\mathrm{MeOH}) 318$ (37.7), and $208 \mathrm{~nm}$ (41.8); ${ }^{1} \mathrm{H}-\mathrm{nmr}(300 \mathrm{MHz}), \delta\left(\right.$ DMSO-d $\left._{6}\right), 2.07$ (s, 3H); 4.73 (t, 2H, J=5.9 Hz); 4.76 (t, $\left.2 \mathrm{H}, \mathrm{J}=6.2 \mathrm{~Hz}\right)$; 
$5.61(\mathrm{~d}, 1 \mathrm{H}, \mathrm{J}=4.1 \mathrm{~Hz}) ; 6.01(\mathrm{t}, 1 \mathrm{H}, \mathrm{J}=4.2 \mathrm{~Hz}) ; 7.02(\mathrm{~d}, 1 \mathrm{H}, \mathrm{J}=2.4 \mathrm{~Hz}) ; 7.5-7.7(\mathrm{~m}, 6 \mathrm{H}) ; 8.0-8.1(\mathrm{~m}, 2 \mathrm{H}) ;$ 8.4-8.5 (m, 2H) ppm.

3-Benzoyl-1-phenyl-5,6-dihydroimidazo[1,2-a]pyrrolo[2,1-c]pyrazin-4-ium-2-anilide (8a). To a solution of 7 ( $210 \mathrm{mg}, 0.4 \mathrm{mmol})$ in dry pyridine $(4 \mathrm{ml})$, aniline $(110 \mathrm{mg}, 1.18 \mathrm{mmol})$ was added and the mixture was stirred at reflux temperature for $16 \mathrm{~h}$. The reaction mixture was then allowed to reach room temperature and evaporated under reduced pressure. The residue was chromatographed on silica gel using a mixture of hexane-ethyl acetate to give $100 \mathrm{mg}(58 \%)$ of a orange solid. Recrystallisation from hexaneethyl acetate afforded pure derivative 8a. Mp $224-225^{\circ} \mathrm{C}$; Found: C,78.21; $\mathrm{H}, 4.95 ; \mathrm{N}, 12.85 . \mathrm{C}_{28} \mathrm{H}_{22} \mathrm{~N}_{4} \mathrm{O}$ requires $\mathrm{C}, 78.11 ; \mathrm{H}, 5.15 ; \mathrm{N}, 13.01$. Ir $(\mathrm{KBr}) v_{\max }=2923,1729,1649,1479,1314,1070 \mathrm{~cm}^{-1} ;{ }^{1} \mathrm{H}-\mathrm{nmr}(300$ $\mathrm{MHz}), \delta\left(\mathrm{CDCl}_{3}\right), 4.47(\mathrm{t}, 2 \mathrm{H}, \mathrm{J}=6.3 \mathrm{~Hz}) ; 4.70(\mathrm{t}, 2 \mathrm{H}, \mathrm{J}=6.2 \mathrm{~Hz}) ; 5.20(\mathrm{~d}, 1 \mathrm{H}, \mathrm{J}=3.0 \mathrm{~Hz}) ; 6.09(\mathrm{t}, 1 \mathrm{H}$, $\mathrm{J}=2.5 \mathrm{~Hz}) ; 7.1-7.2(\mathrm{~m}, 1 \mathrm{H}) ; 7.4-7.6(\mathrm{~m}, 13 \mathrm{H}) ; 7.8-7.9(\mathrm{~m}, 2 \mathrm{H}) \mathrm{ppm}$.

3-Benzoyl-1-phenyl-5,6-dihydroimidazol1,2-a]pyrrolo[2,1-c]pyrazin-4-ium-2diethoxycarbonylmethylide $(\mathbf{8 b})$. To a solution of $7(160 \mathrm{mg}, 0.31 \mathrm{mmol})$ in dry pyridine $(4 \mathrm{ml})$, diethyl malonate $(150 \mathrm{mg}, 0.93 \mathrm{mmol}$ ) was added and the mixture was stirred at reflux temperature for $4 \mathrm{~h}$. The reaction mixture was then allowed to reach room temperature. Evaporation of the solvent under reduced pressure and chromatography of the residue on silica gel using acetone as eluent gave $90 \mathrm{mg}(58 \%)$ of the betaine $8 \mathrm{~b}$. Recrystallisation from acetone afforded orange crystals. Mp $256-257^{\circ} \mathrm{C}$; Found: $\mathrm{C}, 69.75$; $\mathrm{H}, 5.54 ; \mathrm{N}, 8.24 . \mathrm{C}_{29} \mathrm{H}_{27} \mathrm{~N}_{3} \mathrm{O}_{5}$ requires $\mathrm{C}, 70.01 ; \mathrm{H}, 5.47 ; \mathrm{N}, 8.45 . \mathrm{Ir}(\mathrm{KBr}) \mathrm{v}_{\max }=2924,1722,1643$, $1605,1423,1266,1013 \mathrm{~cm}^{-1} ;{ }^{1} \mathrm{H}-\mathrm{nmr}(300 \mathrm{MHz}), \delta\left(\mathrm{CDCl}_{3}\right), 1.27(\mathrm{t}, 6 \mathrm{H}, \mathrm{J}=5.6 \mathrm{~Hz}) ; 4.21(\mathrm{q}, 4 \mathrm{H}, \mathrm{J}=4.7$ $\mathrm{Hz}) ; 4.73$ (t, 2H, J=6.2 Hz); $4.76(\mathrm{t}, 2 \mathrm{H}, \mathrm{J}=5.7 \mathrm{~Hz}) ; 5.62(\mathrm{~d}, 1 \mathrm{H}, \mathrm{J}=4.1 \mathrm{~Hz}) ; 6.14(\mathrm{t}, 1 \mathrm{H}, \mathrm{J}=4.1 \mathrm{~Hz}) ; 6.99$ (d, $1 \mathrm{H}, \mathrm{J}=3.5 \mathrm{~Hz}) ; 7.3-7.4(\mathrm{~m}, 2 \mathrm{H}) ; 7.5-7.7(\mathrm{~m}, 4 \mathrm{H}) ; 8.0-8.4(\mathrm{~m}, 4 \mathrm{H}) \mathrm{ppm}$.

3-Benzoyl-1-phenyl-5,6-dihydroimidazo[1,2-a]pyrrolo[2,1-c]pyrazin-4-ium-2-(2'-benzimidazoylamide) (8c). To a solution of $7(100 \mathrm{mg}, 0.19 \mathrm{mmol})$ in dry pyridine $(3 \mathrm{ml})$ was added 2-aminobenzimidazole $(80 \mathrm{mg}, 0.60 \mathrm{mmol})$ and the mixture was stirred at reflux temperature for $16 \mathrm{~h}$. The reaction mixture was then allowed to reach room temperature and evaporated under reduced pressure. The residue was chromatographed on silica gel (hexane-ethyl acetate 7:3) to give $50 \mathrm{mg}(56 \%)$ of a product identified as the title compound. Recrystallisation from hexane-ethyl acetate afforded orange crystals. Mp $>260{ }^{\circ} \mathrm{C}$; Found: $\mathrm{C}, 74.23 ; \mathrm{H}, 4.77 ; \mathrm{N}, 17.78 . \mathrm{C}_{29} \mathrm{H}_{22} \mathrm{~N}_{6} \mathrm{O}$ requires $\mathrm{C}, 74.02 ; \mathrm{H}, 4.71 ; \mathrm{N}, 17.86$. Ir ( $\mathrm{KBr}$ ) $v_{\max }=3150,1588,11538,1171 \mathrm{~cm}^{-1} ;{ }^{1} \mathrm{H}-\mathrm{nmr}(300 \mathrm{MHz}), \delta$ (DMSO-d 6$), 4.45(\mathrm{t}, 2 \mathrm{H}, \mathrm{J}=5.9 \mathrm{~Hz}) ; 4.72(\mathrm{t}$, $2 \mathrm{H}, \mathrm{J}=5.6 \mathrm{~Hz}) ; 5.19$ (d, 1H, J=4.1 Hz); $6.08(\mathrm{t}, 1 \mathrm{H}, \mathrm{J}=3.9 \mathrm{~Hz}) ; 7.1-7.2(\mathrm{~m}, 1 \mathrm{H}) ; 7.4-7.7(\mathrm{~m}, 13 \mathrm{H}) ; 7.8-7.9$ $(\mathrm{m}, 2 \mathrm{H}) \mathrm{ppm}$.

\section{ACKNOWLEDGEMENTS}

We gratefully acknowledge financial support from Comision Interministerial de Ciencia y Tecnología (CICYT, project PB87-0755).

\section{REFERENCES}

1. (a) Thummel, R.P; Lefoulon, F.; Mahadevan, R. J. Org. Chem., 1985, 50, 3824. (b) Thumel R.P.; Jahng, Y.; J.Org. Chem., 1985, 50, 2407. (c) Thummel, R.P.; Lefoulon, F.; Cantu, D.; Mahadevan R.; J. Org. Chem., 1984, 49, 2208. (d) Thummel, R.P.; Hegde, V. J. Org. Chem., 1989, 54, 1720. 
2. (a) Thummel, R.P.; Lefoulon, F.; Korp, J.D. Inorg. Chem., 1987, 26, 2370. (b) Thummel, R.P.; Lefoulon, F. Inorg. Chem., 1987, 26, 675. (c) Thummel, R.P.; Decloitre, Y. Inorg. Chim. Acta, 1987, 128,245 .

3. Thummel, R.P.; Lefoulon, F.; Chirayil, S.; Guolle, V. J. Org. Chem., 1988, 53, 4745.

4. Thummel, R.P.; Guolle, V.; Chen, B. J. Org. Chem., 1989, 54, 3057.

5. Goulle, V.; Chirayil, s.; Thummel, R.P. Tetrahedron Lett., 1990, 31, 1539.

6. Sliwa, W.; Bachowska, B.; Zelichowicz, N. Heterocycles, 1991, 32, 2241.

7. Coche, L.; Moutet, J.C. J. Electroanal. Chem., 1987, 224, 111.

8. Willner, I.; Steinberger-Willner, B. Int. J. Hydrogen Energy, 1988, 13, 593.

9. Kitazawa, K.; Kobayashi, T.; Shibamoto, T.; Hirai, K. Am. Rev. Respir. Dis., 1988, 137, 173. (Chem. Abstr., 1988, 108, 10779s).

10. Matia, M.P.; Ezquerra, J.; Sanchez-Ferrando, F., Garcia-Navio, J.L., Vaquero, J.J.; Alvarez-Builla, J. Tetrahedron, 1990, 47, 7329.

11. Buchman, R.; Fraser, M.; Kong Thoo Lin, P.V.S. Heterocycles, 1989, $28,857$.

12. Berger, V.; Dreier, F.; Tetrahedron, 1983, 39, 2065.

13. Lown, J.W. in 1,3-Dipolar Cycloaddition Chemistry, Padwa, A., Ed. Wiley-Interscience, New 1984, vol. 2, pp. 653-732.

14. Flament, I.; Sonney, P.; Ohloff, G.; Helv. Chim. Acta, 1977, 60, 1872.

15. Cuadro, A.M.; Matía, M.P.; García, J.L.; Vaquero, J.J.; Alvarez-Builla, J. Synthetic Comm., 1991, 21,535 .

16. Tsuge, O.; Kanemasa, S.; Kuraoka, S.; Takenaka, S; Chem. Lett., 1984, 279.

17. Katritzky, A.R; Grzeskowiak, N.E.; Alvarez-Builla, J. J. Chem. Soc., Perkin Trans. I, 1981, 1180.

18. Padwa, A.; Fryxel, G.E.; Gasdaska, J.R.; Venkatramanan, M.K.; Wong, G.S.K. J. Org. Chem., 1989, 54,644 and references.

19. Alvarez-Builla, J.; Quintanilla, G.; Abril, C.; Gandásegui, M.T.; J. Chem. Research (S), 1984, 202.

20. Gandásegui, M.T.; Alvarez-Builla, J. J. Chem. Research (S), 1986, 74.

21. Molina, A.; Cuadro, A.M.; Novella, J.L.; Vaquero, J.J.; García, J.L.; Alvarez-Builla, J. Tetrahedron, 1990, 46, 6033.

22. Ollis, W.D.; Stanforth, S.P.; Ramsden, C.A.; Tetrahedron, 1985, 41, 2239.

23. Newton, C.G.; Ollis, W.D.; Wright, D.; J. Chem. Soc., Perkin Trans. I, 1984, 69. 